\title{
ON THE DIVERSIFICATION OF FEEDSTOCK IN GASIFICATION OF OIL PALM FRONDS
}

\author{
Shaharin A. Sulaiman ${ }^{1, *}$, Nor Hazwani Mat Razali ${ }^{1}$, Ramzy E. Konda ${ }^{1}$, \\ Samson M. Atnaw ${ }^{1}$ and Mohd Nazmi Z. Moni ${ }^{1}$ \\ ${ }^{1}$ Department of Mechanical Engineering, Universiti Teknologi PETRONAS, \\ 31750 Tronoh, Perak, Malaysia \\ Email: *shaharin@ petronas.com.my \\ Phone: +6053687013; Fax: +6053656461
}

\begin{abstract}
Co-gasification of biomass can be beneficial since relying on only one type of biomass can interrupt operations if the supply of feedstock is disrupted for any reason. Despite this a gasifier system is usually designed for operation with only one specific feedstock. The gasifying of different biomasses can lead to failure or inefficiency. In this work the gasification of different forms of feedstock derived from oil palm frond was tested in an updraft gasifier that was specially designed for oil palm fronds. The feedstocks considered were dried frond blocks, briquetted fronds and overdried (at $150^{\circ} \mathrm{C}$ ) frond blocks. The air flow rate was maintained to the value set for dried fronds in order to investigate the robustness of such configurations. The resulting syngas from the gasification was analyzed in terms of the composition of combustible gases and higher heating value (HHV). Overall, it was found that the altered forms of feedstock caused degradation in the syngas quality, which resulted in a decrease in the HHV of up to $65 \%$.
\end{abstract}

Keywords: Gasification; oil palm fronds; feedstock; syngas; bioenergy.

\section{INTRODUCTION}

A gasifier is normally designed to suit a specific biomass, based on its unique operating characteristics such as the energy content, thermo-chemical properties and water content. As a result, operators would normally rely on one type of biomass in order to avoid complications from the use of different biomasses. Dependency on only one type of biomass for energy generation through gasification is a limitation, however, since supply of the biomass feedstock may be inconsistent due to factors such as weather and competition with bio-product industries. This results in interruption in operations, which consequently affects the reliability and availability of the operation. In many cases, although one biomass may have good gasification properties, the rate of supply of the feedstock within a specific proximity may be too low to be considered feasible. Oil palm fronds, for example, are a potential source of biomass gas for overcoming the problem of depletion in fossil fuels, particularly in Malaysia. While the country's production rate is about 36 million tons per year (Ibrahim, Sapuan, \& Faieza, 2012; Rahman, Wardi, \& Nor, 2013; Wan Zahari, Sato, Furuichi, Azizan, \& Yunus, 2003), oil-palm fronds are generally wasted (Sulaiman, Balamohan, \& Rangkuti, 2008). Decomposition of oil palm fronds for soil nutrition takes a long time and poses a mobilization problem within plantations. Recent studies (Atnaw \& Sulaiman, 2009; Moni \& Sulaiman, 2009; Muda \& Boosroh, 2013; Sulaiman et al., 2008) implied good 
feasibility of oil-palm fronds for gasification. However, the limited localized supply of oil palm fronds is a challenge for a continuous gasification operation. With its low bulk density, it would not be economical to transport the fronds far to collection sites. In addition, storage and transportation derived costs are examples of issues that make certain types of biomasses suitable only for local applications.

Motivated by such limitations, the present research proposal intends to identify a suitable design and operating conditions to enable co-gasification of different biomasses so that gasification can be a more attractive and practical option for alternative energy than it is now. A combination of various forestry and agricultural wastes as feedstock for gasification would provide higher operational flexibility and minimize problems associated with the effect of seasonal supply variations. The biomasses could include wood, rice husks, sawdust, bagasse, palm-fronds, palm trunks etc. To date, studies of co-gasification have been limited only to coal or plastic wastes coupled with another biomass; for example in the works by Pinto et al. (2002), Senneca (2007) and Yuehong, Hao, and Zhihong (2006). At present, only one report (Lapuerta, Hernández, Pazo, \& López, 2008) of a preliminary study of co-gasification of different biomasses can be found, in which the biomasses considered are limited to those available in Mediterranean countries. The gasification process can be complicated as it requires the biomass feedstock to have a low moisture content, typically below 15\% (Moni \& Sulaiman, 2013a). Different moisture content, as a result of different drying intensities or processes, may result in different syngas characteristics and quality (Atnaw, Sulaiman, \& Yusup, 2011). A phenomenon known as bridging (slowing movement of the biomass in the reactor) can occur, resulting in a significant drop in pressure and performance (Guangul \& Sulaiman, 2013). One possible method of overcoming the problem of bridging is to ensure that uniform particle size of biomass feedstock is used, and this includes briquetting of fine feedstock. A unique advantage of briquetting is that it helps minimize the waste resulting from screened fine particles.

The objective of this work was to study the effects of using different forms of feedstock derived from oil palm fronds. The study was conducted using an updraft gasifier that was originally designed for dried oil palm fronds. The feedstock was in the form of dried frond blocks, briquetted fronds and extremely dried (at $150^{\circ} \mathrm{C}$ ) frond blocks. The air flow rate for the gasification process was maintained to the value set for dried fronds in order to investigate the robustness of such configurations.

\section{METHODOLOGY}

An updraft gasifier, as shown in Figure 1, was used in the study. It consisted of a batch type gasifier, air blower, cyclone, cooling unit, oil path filter and gas analyzer. Made from mild steel and cement, the gasifier had a wall thickness of $25 \mathrm{~mm}$ thickness and space volume of $0.16 \mathrm{~m}^{3}$, with a square cross-section. Detailed elaboration of the gasifier system can be found in a previous report (Konda, Sulaiman, \& Ariwahjoedi, 2012). The air flow rate of the blower during gasification was set to deliver at a constant rate of $280 \mathrm{lpm}$. The feedstock was in the form of dried frond blocks, briquetted fronds and extremely dried frond blocks. The oil palm fronds were obtained from a plantation in the state of Perak, Malaysia. The leaflets of the ordinary dried fronds were cut, leaving only the petiole. The fronds were cut into cubes with approximately $25 \mathrm{~mm}$ edges. There were dried to $10-12 \%$ of their moisture content. The other form of frond feedstock was prepared to dice size of $2-4 \mathrm{~mm}$ and was dried at $150^{\circ} \mathrm{C}$ for 24 hours in a drying oven. 
The briquette was prepared by mixing components of ground fronds which were segregated in a two-stage sieving. Using a commercial grinder, the fronds were turned into a heterogeneous mixture of long hairy fibers, diced particles and dust. The first stage of sieving used a $10 \mathrm{~mm}$ square wire mesh and this trapped the fibers. The bulk density of the fiber was found to be about $0.040 \mathrm{~g} / \mathrm{cm}^{3}$. In the second stage of sieving, which used a $5 \mathrm{~mm}$ square wire mesh, the diced particles were trapped and fine dust was allowed to pass through. The diced particles were approximately uniform and would normally be used for gasification. A briquette was formed from the mixture of the sawdust, diced fronds, and leaflets at a ratio of 5:5:2. Details of the preparation procedure of the briquette can be found in an earlier publication (Moni \& Sulaiman, 2013b). The leaflet was included in the briquette as it had been previously wasted due to its light weight. The briquette had a diameter of $10.5 \mathrm{~cm}$ and thickness of $2.5 \mathrm{~cm}$, and a hole at the center with a diameter of $3 \mathrm{~cm}$. Each piece of briquette had a weight of between 35 and 55 grams.

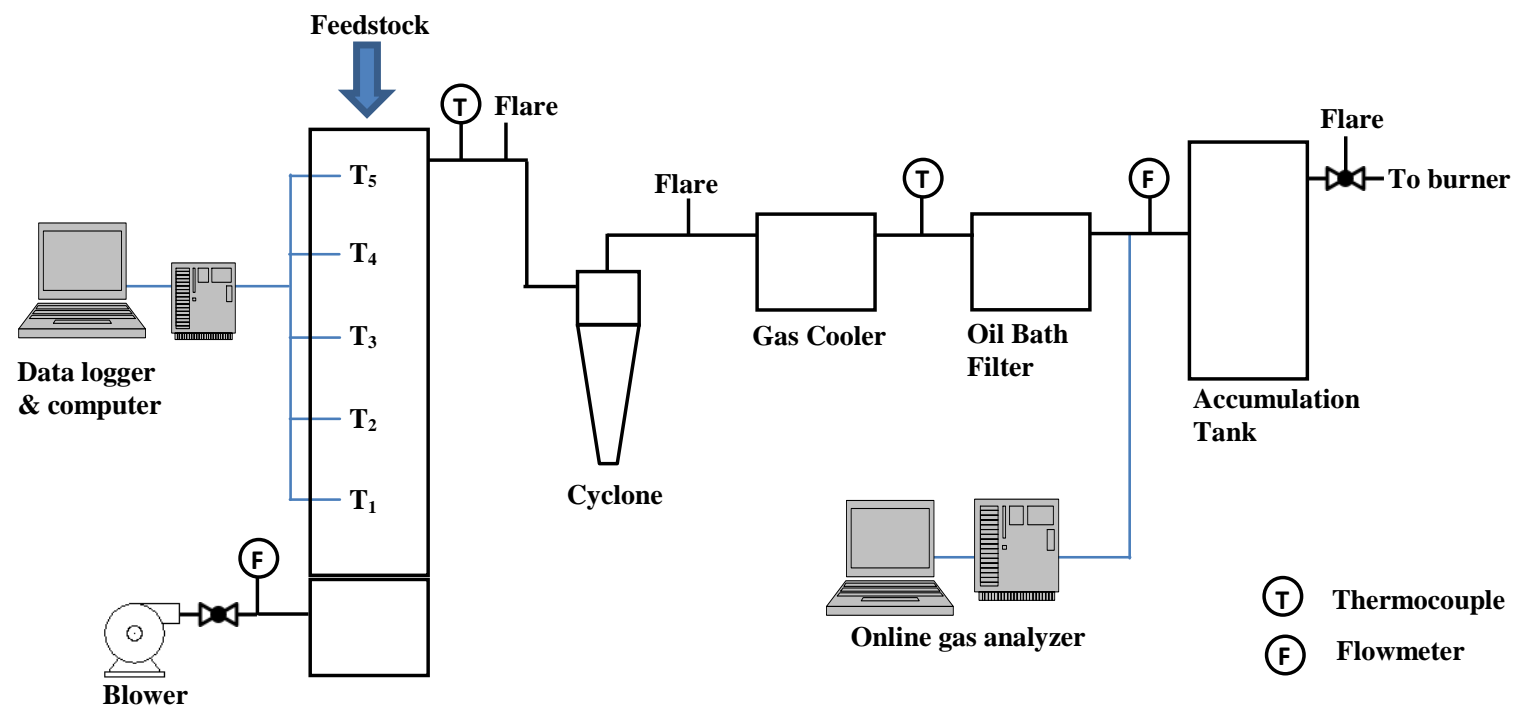

Figure 1. Schematic of the experiment setup

A final analysis was not performed for the leaflets of the fronds. Table 1 shows the CHNS composition of the leaflets, which is compared with those for the petiole. It can be seen from the Table, that the difference in CHNS composition between the two was small, except that the nitrogen content of the leaflet was significantly higher. The resulting syngas was sampled and cleaned using a system that consisted of an electric gas cooler, a diaphragm pump, a $4 \mu \mathrm{m}$ ceramic filter, and a rotameter with a valve for gas flow control. To measure the gas composition, an Emerson X-Stream X2GP gas analyzer was used. A detailed description of the procedure can be found in a previous publication (Guangul, Sulaiman, \& Ramli, 2012).

Table 1. Ultimate analysis results for petiole and leaflet

\begin{tabular}{ccc}
\hline Type of Elements & Petiole $(\%)$ & Leaflet $(\%)$ \\
\hline $\mathrm{C}$ & 41.33 & 41.20 \\
$\mathrm{H}$ & 5.30 & 4.81 \\
$\mathrm{~N}$ & 0.22 & 2.89 \\
$\mathrm{~S}$ & 0.22 & 0.34 \\
\hline
\end{tabular}




\section{RESULTS AND DISCUSSION}

Figure 2 shows the variation of syngas composition with time as a result of gasification of the selected biomass feedstock. Figures $2 \mathrm{a}$ to $2 \mathrm{c}$ show the results for ordinary dried fronds, briquettes and overdried fronds, respectively. The fluctuations of gas composition in Figures $2 \mathrm{~b}$ and $2 \mathrm{c}$ imply bridging, which was more significant for the briquette. Overall, a common trend in all the graphs is that $\mathrm{CH}_{4}$ content was the lowest for all feedstock, followed by $\mathrm{H}_{2}$. On the other hand, the content of $\mathrm{CO}$ was the highest for all except briquettes. The $\mathrm{CO}_{2}$ content was significantly high for briquettes, as shown in Figure $2 \mathrm{~b}$. It is probable that combustion dominated the process involving the briquette and thus an adjustment in the airflow rate would be necessary. It is also shown in Figure 2 that the gas composition was relatively lower for the briquette compared to other feedstock. This was probably due to the bridging resulting from the early breakage of the briquette, which was observed to be poorly intact, thus limiting the reaction in the gasifier. In general, it can be deduced from Figure 2 that a modification of feedstock, through briquetting or over drying, would not enhance the gasification process and output if the flow rate was maintained in favor of that for ordinary dried fronds.

The graphs of the temperature profile for the processes using three different feedstock materials are shown in Figures $3 \mathrm{a}$ to $3 \mathrm{c}$. The process started with combustion which supplied heat to initiate gasification. Once steady combustion was achieved, the air supply blower was operated and the oxidation zone temperature $\left(\mathrm{T}_{1}\right)$ increased to between $500^{\circ} \mathrm{C}$ and $800^{\circ} \mathrm{C}$ within 10 minutes. The experiments lasted between 60 and 70 minutes. The oxidation temperature was the highest for ordinary dried fronds, which reached a maximum value of $820^{\circ} \mathrm{C}$. In addition, the gasification of ordinary dried fronds was shown to sustain oxidation temperatures of above $700^{\circ} \mathrm{C}$ (typical minimum gasification temperature) for approximately 48 minutes, after which the temperature dropped, probably because most of the feedstock was already consumed in this batch operation system. The reduction zone temperature $\left(T_{2}\right)$ for gasification of ordinary dried fronds also showed a similar pattern, except that the temperature dropped to below $300^{\circ} \mathrm{C}$ after the $30^{\text {th }}$ minute of operation. The temperatures of the other zones (pyrolysis and drying), represented by $\mathrm{T}_{3}, \mathrm{~T}_{4}$, and $\mathrm{T}_{6}$, are shown to be relatively small and stable. The overall temperature profile in the gasification process for ordinary dried fronds is in agreement with the range of zone temperature values reported in the literature (Borisov, Geîetuha, \& Khalatov, 1998; Zainal, Rifau, Quadir, \& Seetharamu, 2002).

The acceptable performance of the gasification of ordinary dried fronds in Figure $3 \mathrm{a}$ was the result of previous laborious attempts based on theory and also tedious trial and error. However, when modified feedstock materials were used, the gasification performances were shown to deteriorate, as seen in Figures $3 b$ and $3 c$. The results in Figure $3 b$ correlate well with those in Figure $2 b$, of which it was suggested that gasification did not take place for the briquette. 


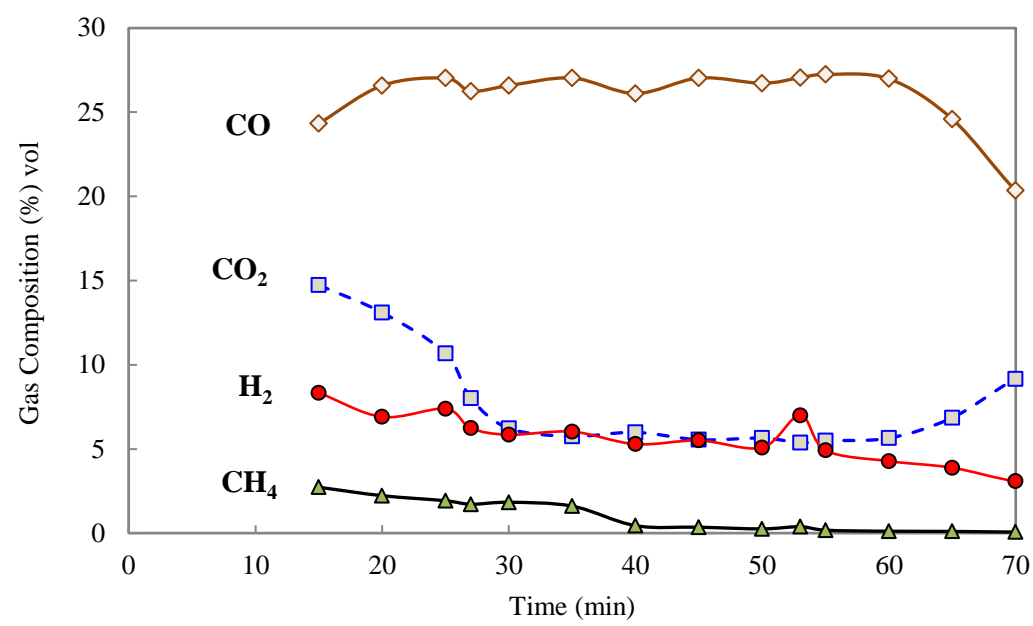

(a)

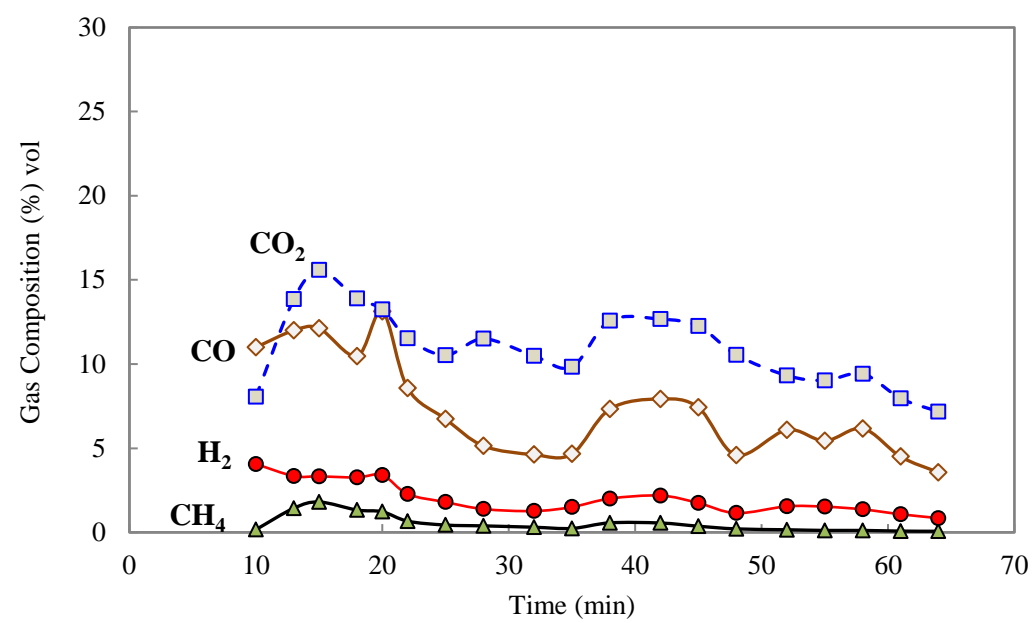

(b)

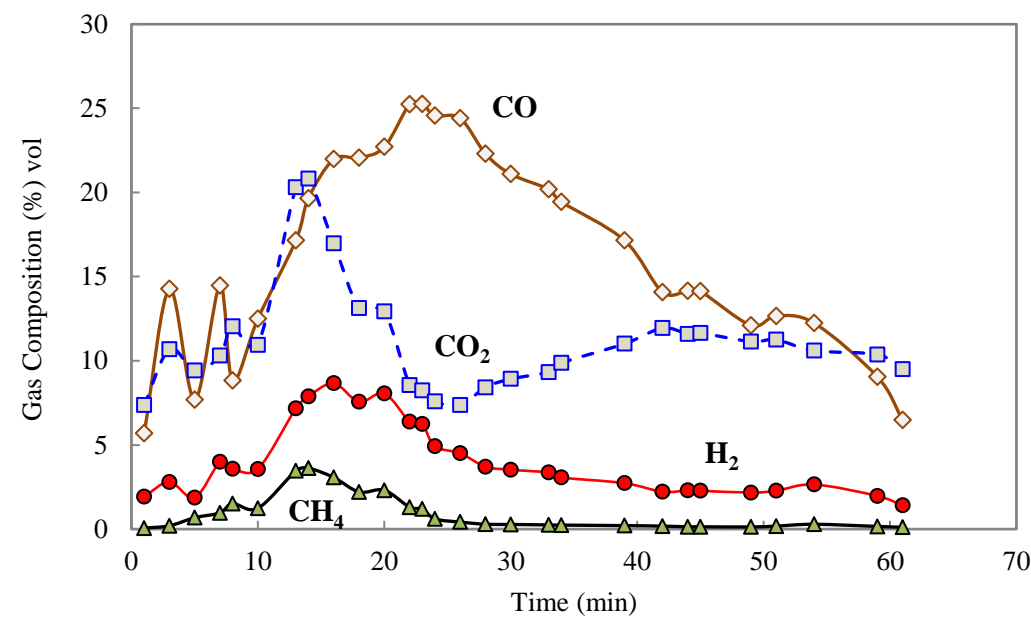

(c)

Figure 2. Variation of syngas composition with time: (a) ordinary dry fronds, (b) briquette, (c) overdried fronds. 
On the diversification of feedstock in gasification of oil palm fronds

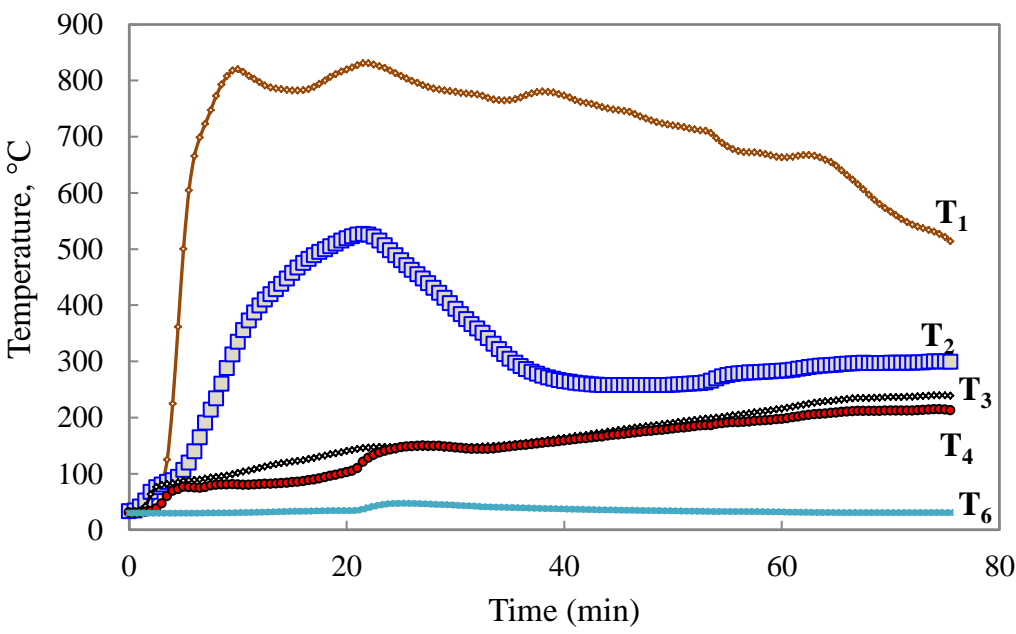

(a)

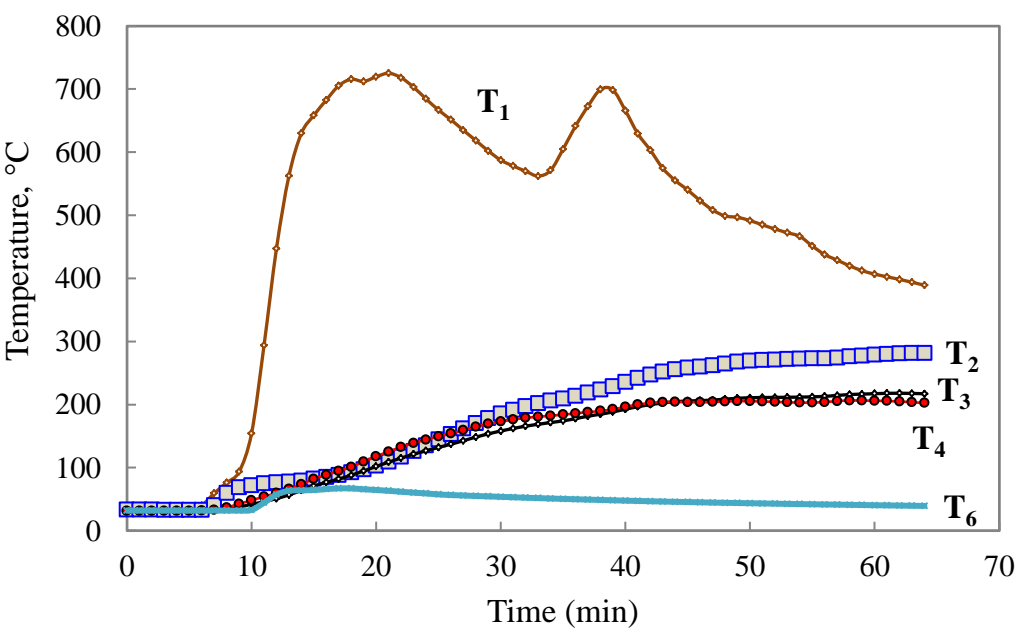

(b)

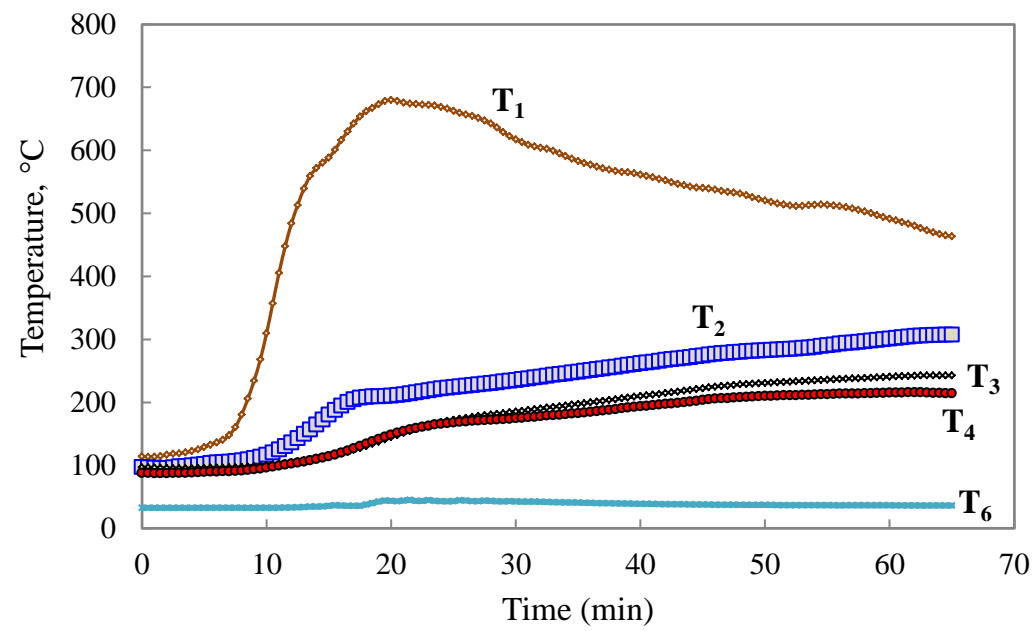

(c)

Figure 3. Temperature profile during gasification: (a) ordinary dry fronds, (b) briquette, (c) overdried fronds. 
Figures $3 \mathrm{~b}$ and $3 \mathrm{c}$ show that the oxidation temperature $\left(\mathrm{T}_{1}\right)$ for briquette and overdried frond barely reached the $700^{\circ} \mathrm{C}$ that would be required for a proper gasification process to take place. However, there was a quite significant amount of $\mathrm{CO}$ and $\mathrm{H}_{2}$ gases in the syngas resulting from the gasification, particularly for the overdried frond. This suggests that it was probably a combination of pyrolysis, gasification and direct combustion that took place in the reactor during the experiments with the briquette and overdried frond. To evaluate the effectiveness of the gasification process, the higher heating value (HHV) of the syngas gas in its dry form (through gas conditioning) was calculated. The HHV of the syngas (in $\mathrm{MJ} / \mathrm{Nm}^{3}$ ) was determined by:

$$
\mathrm{HHV}=4.1868 \times\left[\left(\mathrm{H}_{2} \% \times 30.52\right)+(\mathrm{CO} \% \times 30.18)+\left(\mathrm{CH}_{4} \% \times 95\right)\right]
$$

of which $\mathrm{H}_{2} \%, \mathrm{CO} \%$ and $\mathrm{CH}_{4} \%$ are the volumetric percentage of the component gases in the flue gas (Xiao, Zhang, Jin, Huang, \& Zhou, 2006). Table 2 shows the average compositions and the HHV of the resulting syngas for the feedstock materials. The ordinary dried frond, which served as the baseline, has an HHV of $4.29 \mathrm{MJ} / \mathrm{Nm}^{3}$. Nevertheless, the attempt to gasify the briquette using the same setting resulted in a significantly low $\mathrm{HHV}$ of $1.50 \mathrm{MJ} / \mathrm{Nm}^{3}$. The overdried frond $\left(150^{\circ} \mathrm{C}, 24\right.$ hours $)$ had a better $\mathrm{HHV}$ at $2.96 \mathrm{MJ} / \mathrm{Nm}^{3}$ but was still far below the baseline. The overdried was better than the briquette probably because its shape and size meant it's reaction was easier. From Table 2 it can be deduced that modifying the feedstock would significantly affect the performance of gasification even though the feedstock originates from the same base biomass materials. Adjustment in the operation of gasification and probably in the design of gasifier would be required in order to enable gasification of different feedstock in a single gasifier.

Table 2. Average compositions of resulting syngas and higher heating value (HHV) of different feedstock materials

\begin{tabular}{|c|c|c|c|c|c|}
\hline \multirow{2}{*}{ Gasification Feedstock } & \multicolumn{4}{|c|}{ Average Composition of Gas (\%) } & \multirow{2}{*}{$\begin{array}{c}\mathrm{HHV} \\
\left(\mathrm{MJ} / \mathrm{Nm}^{3}\right)\end{array}$} \\
\hline & $\mathrm{CO}$ & $\mathrm{CO}_{2}$ & $\mathrm{H}_{2}$ & $\mathrm{CH}_{4}$ & \\
\hline Ordinary dry fronds & 25.39 & 7.93 & 5.51 & 0.94 & 4.29 \\
\hline Briquette (frond-based) & 8.07 & 11.02 & 2.06 & 0.54 & 1.50 \\
\hline Fronds dried $\left(150^{\circ} \mathrm{C}, 24 \mathrm{~h}\right)$ & 16.48 & 11.15 & 4.03 & 0.91 & 2.96 \\
\hline
\end{tabular}

\section{CONCLUSIONS}

An attempt to gasify different forms of feedstock derived from oil palm frond was made in this work, using ordinary dried frond blocks, briquetted fronds and overdried frond blocks. It can be concluded that alteration of the forms of feedstock resulted in a decrease in the HHV of the syngas by up to $65 \%$ relative to its original form. In addition, the gasifier system was found not to be robust when handling feedstock materials of different forms even though they were made of the same base materials. A proposed reason for the poor performance of the briquette was that it was so brittle that it broke too early and thus affected the gasification process. As a result, it may not be possible to simply change biomass feedstock materials without altering the air flow rate or gasifier design. Further study would be required. 


\section{ACKNOWLEDGEMENT}

This project was partly funded by the Ministry of Higher Education through the Exploratory Research Grant Scheme (Persson, Hogmark, \& Bergström) fund No. 15-8200-313.

\section{REFERENCES}

Atnaw, S. M., \& Sulaiman, S. A. (2009, 7-8 Dec. 2009). Modeling and simulation study of downdraft gasifier using oil-palm fronds. 3rd International Conference on. Energy and Environment, 2009. ICEE 2009.

Atnaw, S. M., Sulaiman, S. A., \& Yusup, S. (2011). A simulation study of downdraft gasification of oil-palm fronds using aspen plus. Journal of Applied Sciences, 11(11), 1913-1920.

Borisov, I. I., Geîetuha, G. G., \& Khalatov, A. A. (1998). Performance and characteristics of wood downdraft gasifier with vortex gas cleaning system. Paper presented at the $)^{\wedge}($ Eds.): 'Book Performance and characteristics of wood downdraft gasifier with vortex gas cleaning system'(Biomass for energy and industry. Proc. 10th European conference and technology exhibition (Eds. H. Kopetz et al.), 1998, edn.).

Guangul, F. M., \& Sulaiman, S. A. (2013). Mitigation of bridging problem in biomass gasification by a novel approach. Asian Journal of Scientific Research, 6(2).

Guangul, F. M., Sulaiman, S. A., \& Ramli, A. (2012). Gasifier selection, design and gasification of oil palm fronds with preheated and unheated gasifying air. Bioresource Technology, 126(0), 224-232.

Ibrahim, M. S., Sapuan, S. M., \& Faieza, A. A. (2012). Mechanical and thermal properties of composites from unsaturated polyester filled with oil palm ash. Journal of Mechanical Engineering and Sciences, 2, 133-147.

Konda, R. E., Sulaiman, S. A., \& Ariwahjoedi, B. (2012). Syngas production from gasification of oil palm fronds with an updraft gasifier. Journal of Applied Sciences, 12(24).

Lapuerta, M., Hernández, J. J., Pazo, A., \& López, J. (2008). Gasification and cogasification of biomass wastes: Effect of the biomass origin and the gasifier operating conditions. Fuel Processing Technology, 89(9), 828-837.

Moni, M. N. Z., \& Sulaiman, S. A. (2009). Development of a biomass downdraft gasifier for oil palm fronds. Paper presented at the 2nd National Postgraduate Conference on Engineering, Science and Technology, Tronoh.

Moni, M. N. Z., \& Sulaiman, S. A. (2013a). Downdraft gasification of oil palm frond: Effects of temperature and operation time. Asian Journal of Scientific Research, 6(2), 197-206.

Moni, M. N. Z., \& Sulaiman, S. A. (2013b). Preliminary study of oil palm frond briquette as biomass fuel for gasification. Paper presented at the 3rd International Conference and Exhibition on Sustainable Energy and Advanced Materials (ICE-SEAM 2013), Melaka.

Muda, N., \& Boosroh, M. H. (2013). Gasification of coal-petcoke blends in a pilot scale gasification plant. International Journal of Automotive and Mechanical Engineering, 8, 1457-1466. 
Persson, A., Hogmark, S., \& Bergström, J. (2005). Thermal fatigue cracking of surface engineered hot work tool steels. Surface and Coatings Technology, 191(2), 216227.

Pinto, F., Franco, C., André, R. N., Miranda, M., Gulyurtlu, I., \& Cabrita, I. (2002). Cogasification study of biomass mixed with plastic wastes. Fuel, 81(3), 291-297.

Rahman, M. M., Wardi, M. A. S., \& Nor, S. S. M. (2013). On the effect of feedstock preparation on the characteristics of warm formed powder compacts. International Journal of Automotive and Mechanical Engineering, 8, 11321139.

Senneca, O. (2007). Kinetics of pyrolysis, combustion and gasification of three biomass fuels. Fuel Processing Technology, 88(1), 87-97.

Sulaiman, S. A., Balamohan, S., \& Rangkuti, C. (2008). Studies on suitability of palmfronds for biomass gas production.

Wan Zahari, M., Sato, J., Furuichi, S., Azizan, A. R., \& Yunus, M. (2003). Commercial processing of oil palm fronds feed in malaysia. Paper presented at the 8th meeting of the Regional Working Group on Grazing and Feed Resources for Southeast Asia, Kuala Lumpur, Malaysia.

Xiao, R., Zhang, M., Jin, B., Huang, Y., \& Zhou, H. (2006). High-temperature air/steam-blown gasification of coal in a pressurized spout-fluid bed. Energy \& Fuels, 20(2), 715-720.

Yuehong, Z., Hao, W., \& Zhihong, X. (2006). Conceptual design and simulation study of a co-gasification technology. Energy Conversion and Management, 47(1112), 1416-1428.

Zainal, Z. A., Rifau, A., Quadir, G. A., \& Seetharamu, K. N. (2002). Experimental investigation of a downdraft biomass gasifier. Biomass and Bioenergy, 23(4), 283-289. 